\title{
Dengue fever associated with extreme reactive thrombocytosis
}

\author{
UK Egodage $^{1}$, NUA Dissanayake ${ }^{1}$, MU Dahanayake ${ }^{1}$, CK Bodinayake $^{1}$
}

Ceylon Medical Journal 2016; 61: 194-195

http://doi.org/10.4038/cmj.v61i4.8391

\section{Introduction}

Dengue is an important viral illness which has the potential to progress into dengue hemorrhagic fever (DHF) or dengue shock syndrome (DSS). Leucopenia and throm-bocytopenia are the hallmarks of acute dengue which normalise with recovery [1]. Progression from thrombo-cytopenia to severe thrombocytosis is uncommon. We describe a patient presenting with acute dengue, who developed extreme reactive thrombocytosis.

\section{Case report}

A 22-year old female was admitted with fever, headache, myalgia and arthralgia of 5 days duration. There was no evidence of fluid leak or bleeding. The patient was stable throughout illness. There was leucopenia (WBC $3.5 \times 10^{3} / \mu \mathrm{l}$ ) with a hemoglobin level of $(\mathrm{Hb}) 12.2 \mathrm{~g} / \mathrm{dl}$ and packed cell volume of $38 \%$. Dengue $\mathrm{IgM}$ antibodies were positive and dengue IgG antibodies were negative. The platelet count progressively declined from $249 \times 10^{3} / \mu 1$ on $2^{\text {nd }}$ day to $104 \times 10^{3} / \mu 1$ on $7^{\text {th }}$ day of illness. The patient recovered and went home on the $9^{\text {th }}$ day of illness with a platelet count of $154 \times 10^{3} / \mu 1$.

One week later, the patient presented with fatigue and breathlessness. The body temperature was $37^{\circ} \mathrm{C}$, pulse rate was 94/bpm, blood pressure was $110 / 70 \mathrm{~mm} \mathrm{Hg}$ and oxygen saturation was $98 \%$. There was no lymphadenopathy or organomegaly. The platelet count was $903 \times 10^{3} /$ $\mu \mathrm{l}$, white cell count was $9.5 \times 10^{3} / \mu \mathrm{l}$ and $\mathrm{Hb}$ was $10 \mathrm{~g} / \mathrm{dl}$. The chest radiograph, ECG, echocardiogram, abdominal ultra-sound and the arterial duplex of the lower limbs were normal. The platelets remained persistently elevated for two weeks with the maximum recorded at $1015 \times 10^{3} / \mu 1$. A diagnosis of reactive thrombocytosis was made. The patient was well hydrated and was kept under observation. Clopidogrel $75 \mathrm{mg}$ was commenced to prevent possible thrombosis. The platelets remained elevated above $500 \times 10^{3} / \mu 1$ for 14 more days, gradually declined and normalised to $452 \times 10^{3} 3 / \mu 1$. Clopidogrel was discontinued after normalisation of platelets. On follow up, the patient was asymptomatic and had normal blood counts.

\section{Discussion}

Kinetic description of platelet count in dengue shows that platelet count progressively decrease from $3^{\text {rd }}$ day to $7^{\text {th }}$ day of illness and increase to normal levels around the $8^{\text {th }}$ day of illness [2]. The mechanisms involved in thrombocytopenia and bleeding during dengue virus (DENV) infection is not fully understood. It is postulated that DENV directly or indirectly affect bone marrow progenitor cells by inhibiting the proliferative capacity of hematopoietic cells [3].

Thrombopoietin (TPO) specifically regulates megakaryocytopoiesis and platelet production by activating the TPO receptor c-MPL (myeloproliferative leukemia virus oncogene). The concentration of circulating TPO is abnor-mally high in reactive thrombocytosis similar to auto-immune diseases, infections, or malignancies. TPO levels are shown to be significantly increased in dengue with severe thrombocytopenia and are inversely related to the platelet count [4]. Increased levels of TPO occur at the same period as the disease reaching a peak at the defervescence, when platelet nadir occurs, and decline to normal levels with remission of thrombocytopenia [5]. Rebound thrombocytosis is proportionate to the severity of the preceding thrombocytopenia and follow-up platelet counts are significantly higher in adults with DSS compared to adults with DF [6]. There is no concordance with regard to management of reactive thrombocytosis. According to British guidelines on treatment for reactive thrombocytosis $75 \mathrm{mg}$ of aspirin is suggested, but there is no published data to support this practice [10].

\section{Consent}

Informed, written consent was obtained from the patient for publication of the details.

\section{Conflicts of interest}

There are no conflicts of interest.

${ }^{1}$ University Medical Unit, Teaching Hospital, Karapitiya, Galle, Sri Lanka.

Correspondence: UKE, e-mail: <kaushiegodage@gmail.com>. Received 11 March 2016 and revised version accepted 31 May 2016. and reproduction in any medium, provided the original author and source are credited. 


\section{References}

1. Gibbons RV, Vaughn DW. Dengue: an escalating problem. $B M J$ 2002; 324: 1563-6.

2. Srichaikul T, Nimmannitya S. Haematology in dengue and dengue haemorrhagic fever. Best Pract Res Clin Haematol 2000; 13: 261-76.

3. Murgue B, Cassar O, Guigon M, Chungue E. Dengue virus inhibits human hematopoietic progenitor growth in vitro. $J$ Infect Dis 1997; 175: 1497-501.

4. Matondang AV, Widodo D, Zulkarnain I, et al. The correlation between thrombopoietin and platelet count in adult dengue viral infection patients. Acta Med Indones 2004; 36: 62-9.
5. Cardier JE, Balogh V, Perez-Silva C, et al. Relationship of thrombopoietin and interleukin-11 levels to thrombocytopenia associated with dengue disease. Cytokine 2006; 34: 155-60.

6. Thu TL, Minh DN, Van NT, et al. Clinical features of dengue in a large Vietnamese cohort: intrinsically lower platelet counts and greater risk for bleeding in adults than children. PLo S Negl Trop Dis 2012; 6: e1679.

7. Harrison CN, Bareford D, Butt N, et al. Guideline for investigation and management of adults and children presenting with a thrombocytosis. Br J Haematol 2010; 149: 352-75. 